\title{
Expression Analysis of Fox-2 Alternative Isoforms during Neuronal Differentiation
}

\author{
Nor Hakimah Ab Hakim ${ }^{1 *}$ Burhanuddin Yeop Majlis ${ }^{1,}$ Hitoshi Suzuki ${ }^{2}$ and Toshifumi Tsukahara ${ }^{2}$
}

\begin{abstract}
We analyzed Fox proteins in neuronal differentiation of P19 cells. Fox-1 was specifically observed in the neural cell stage (Day 7). We found Fox-1 was able to regulate alternative splicing of a transcription factor, Mef2c. It was suggested that neural-specific inclusion of - Mef2c exon - * was promoted by Fox-1. Fox-2 showed similar function in promoting Mef2c exon $\cdot$ • inclusion. However, Fox-2 expression was observed in undifferentiated cells and increase slightly in the differentiation. Our result of Exon Array analysis suggested Fox- 2 has one of alternative exons, which changed in neuronal differentiation. Essentially, long isoform of Fox-2, expressing in undifferentiated P19 cells, was replaced into short isoforms of Fox-2 in the differentiation. Our preliminary result suggested short isoforms strongly affected alternative splicing in one of known targets of Fox-1, compared with long isoform of Fox-2. Taken together, Fox-1 and alternative isoforms of Fox-2 were expressed during neuronal differentiation of P19 cells, and contributed to regulate neural splicing event.
\end{abstract}

Index Terms - Alternative Splicing, Neural Differentiation, P19 Cells, Splicing Regulator

\section{INTRODUCTION}

Alternative splicing is one of the common ways for regulation of eucaryotic gene expression [1-4]. It is known as a major contributor towards proteomic diversity because of its mechanism which allows generation of multiple proteins from one single gene $[5,6]$. It is known that $90 \%$ of human genes undergo alternative splicing [7]. One of the most famous examples is the Dscam gene of Drosophila which has the potential to encode more than 38,000 proteins from one single gene [8].

There are several types of alternative splicing and the most common one is exon skipping (also known as cassette exon). Besides that, the other known alternative splicing events are alternative 5' splice sites, alternative 3' splice sites, intron retention and mutually exclusive exons (reviewed in 8,9). Since combinations of exons are changed in alternative splicing events, it may be possible that the isoforms have different functions or activities.

P19 cells are frequently used in differentiation of cells into specific tissues such as neurons. This is because P19 cells,

\footnotetext{
1 Institute of Microengineering and Nanoelectronics (IMEN), Universiti Kebangsaan Malaysia, 43600 UKM Bangi, Selangor Darul Ehsan, Malaysia.

${ }^{2}$ School of Materials Science, Japan Advanced Institute of Science and Technology, 1-1 Asahidai, Nomi, Ishikawa 923-1292, Japan.
}

which are a line of pluripotent embryonal carcinoma, can grow continuosly in media that is supplemented with serum [10]. P19 cells are used widely to understand the mechanism of differentiation, and the development of cells into neurons. By treatment with retinoic acid, we can observe neuronal differentiation.

The determination in changes of splicing pattern is influenced by regulatory proteins which bind to the pre-mRNA and enhance or silence particular splicing choices (reviewed in $2,9,11)$. There are two kinds of splicing regulators which are known as positive and negative factors. The best described positive factors are the serine-arginine-rich proteins (SR proteins) and their relatives. On the other hand, negative factors include the hnRNP group, for instance, hnRNP A1 and PTB (reviewed in 2, 9,11).

Originally identified in Caenorhabditis elegans, Fox-1 gene (feminizing locus on $\mathrm{X}$ ) functions as numerator element in counting the number of $\mathrm{X}$ chromosomes relative to ploidity. Besides that, Fox-1 gene also plays a role in the determination of male or hermaphrodite development [13-15]. Fox -1 is an RNA - binding protein which contains an RNA recognition motif (RRM). It has been reported that Fox -1 is expressed in brain, heart and skeletal muscle in mouse [16]. Furthermore, Jin Y. et al. showed that zebrafish Fox -1 protein binds specifically to the pentanucleotide GCAUG from their SELEX experiments [17].

It has been reported that in mammals, Fox-1 has three family members, which are Fox-1, Fox-2 and Fox-3. Both the Fox-1 and Fox-2 are closely related since they have an identical RNA recognition motif (RRM) domain. [18]. Moreover, Fox-1 is also well known as ataxin-2 binding protein 1 or in short, A2BP1 and another name for Fox-2 is RNA-binding motif protein 9, RBM9. Furthermore, the latest addition to the family, Fox-3, still not very well understood and characterized.

\section{EXPERIMENTAL PROCEDURES}

\section{A. Cell Culture and Cell Differentiation}

P19 cells were grown in $\alpha$-MEM (Minimum Essential Medium, $\alpha$, Wako) supplemented with 10\% FBS (fetal bovine serum, Hyclone). Meanwhile, induction for neural cell differentiation of P19 cells was performed essentially as previously described [19]. P19 cells (1x105 cells/ml) were treated with $1 \mu \mathrm{M}$ of retinoic acid for 4 days in the $10 \mathrm{~cm}$ petri dish (Falcon). HEK293 cells were grown in DMEM 
(Dullbecco's Modified Eagle's Medium) supplemented with $10 \%$ FBS (fetal bovine serum, Hyclone).

\section{B. RNA isolation and Reverse Transcriptase Polymerase Chain Reaction (RT-PCR)}

Total RNAs were collected from cells and tissues by Trizol reagent (Invitrogen). cDNAs were synthesized from $2 \mu \mathrm{g}$ of total RNAs using SuperScript III (Invitrogen) and $0.5 \mu \mathrm{g}$ of oligo dT primer in $20 \mu \mathrm{l}$ reaction. These cDNAs are used as template for the PCR. The PCRs were performed by GoTaq polymerase (Promega) and specific primers. The sequence of DNA primers, number of cycles, and annealing temperature are as follows. Detection of - -actin as a general control: • -actin fw (CAACGAGCGGTTCCGATG) \& - -actin rv (GCCACAGGATTCCATACCCA), 28 or 22 cycles, and $56^{\circ} \mathrm{C}$. Detection of glutamate receptor 1 as a neural marker: gluR $1 \mathrm{fw}$ (CTCTGAGCCTGAGCAATGTG) \& rv (GATGGATTGCTGTGGAATCA), 30 or 25 cycles, and $56^{\circ} \mathrm{C}$. Detection of alternative splicing regulators; Fox-1: fox- $1 \mathrm{fw}$ (CCTTCTGAAAACACAGAAAGCA) \& rv (TGGTGTAGGGGTTGACAGTCT), 25 cycles, and $58^{\circ} \mathrm{C}$, Fox-2: fox-2 fw (AATCTACGCCCAACCGACTA) \& rv (CGTGACCATCTTCTTGTTGG). Detection of Fox-2 alternative promoters; Fox-2 $\mathrm{m} 1$ : fox-2 $\mathrm{m} 1 \mathrm{fw}$ (GGGAGTCGGAGGTGGAGT), Fox-2 $\mathrm{m} 2$ : fox-2 $\mathrm{m} 2 \mathrm{fw}$ (TTCCAGGAAGGAAGAGAGAGTG), Fox-2 m3: fox-2 m3 fw (TTCCAACTGGTTATCATCTGCTT), \& reverse primer for all alternative promoters; rv (CTGTGGGAATTCCATTTTGTG), 25 cycles, and $60^{\circ} \mathrm{C}$.

PCR products were analyzed in $6 \%$ polyacrylamide gel or $2 \%$ agarose gel. The gels were stained with $\mathrm{EtBr}$ or Sybr Green I (Takara) and the images were analyzed in UV-trans illuminator (Vilber Lourmat) or LAS-3000 (Fuji film).

\section{RESUlts AND Discussion}

\section{A. Screening For Other Alternative Exons}

In our previous work, we analyzed Fox proteins in neuronal differentiation of P19 cells. Fox-1 was specifically observed in the neural cell stage which is Day 7. We found Fox-1 was able to regulate alternative splicing of a transcription factor, Mef2c. Our result suggested that neural-specific inclusion of - Mef2c exon - - was promoted by Fox-1 [20]. Fox-2 showed similar function in promoting Mef2c exon - • • inclusion. However, Fox-2 expression was observed in undifferentiated cells and increased slightly in the differentiation. Fox-1 promoted exon - - inclusion via the GCAUG sequence located in the adjacent intron of Mef2c exon - • [20] - In this regulation, GCAUG sequence act as cis element [20]. Nevertheless, regulation by Fox-1 alone seems not enough. We hypothesized that some other factor may co-regulate this splicing regulation.

\section{B. Fox-2 alternative isoforms during neural differentiation}

It has been reported that the three Fox homologues genes are very complex in mammals since they have alternative exons, alternative splice sites as well as multiple promoters. They are able to produce complex sets of proteins which have different $\mathrm{N}$ - and C-terminus domains and also differing in their subcellular distributions [21].

In order to clarify the expression patterns of Fox-2 isoforms, we carried out expression analysis of Fox-2 isoforms during neural differentiation of P19 cells by semi-quantitative RT-PCR. From our experiments, remarkably, short isoforms of Fox-2 (m2 and $\mathrm{m} 3$ ) were highly expressed on day 7 , which is the neural cell stage. On the other hand, long isoform of Fox-2 (m1) expression was observed in undifferentiated P19 cells.

In the study by Guang et. al. (2008), they detected changes from short isofrom, Fox-2 F (m3) to the long isoform, Fox-2 A (m1) which promoted inclusion of exon 16 of Epb4.1R gene during erythroid differentiation [22].

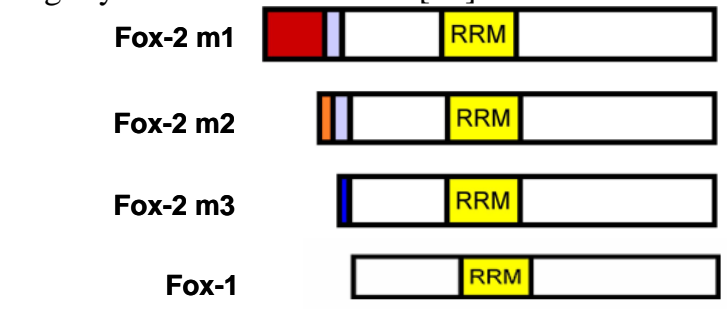

(A)

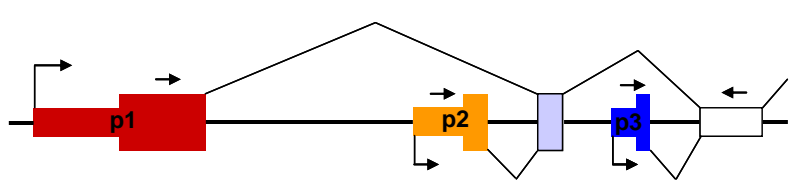

(B)

Fig. 1 (A) Schematic representation of Fox-2 isoforms. (B) Schematic representation of Fox-2 gene structure. It has at least three alternative splicing promoters which expressed in P19 cells.
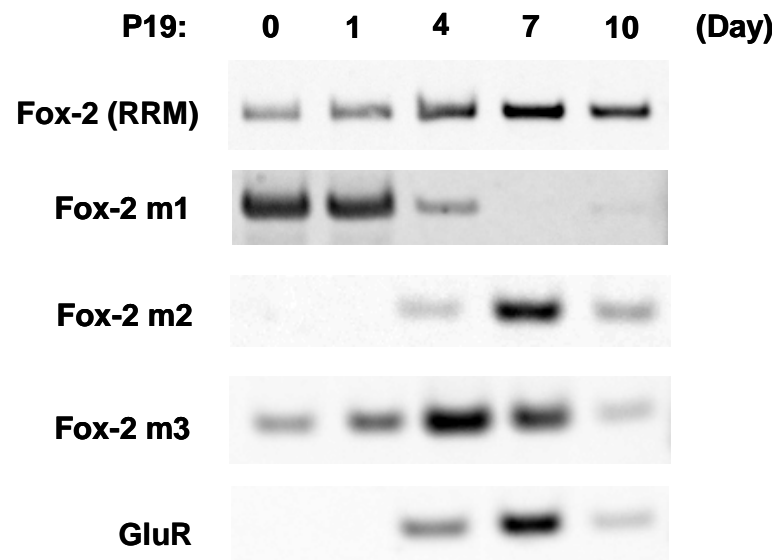

\section{$\beta$-Actin}

Fig. 2 RT-PCR of Fox-2 alternative splicing isoforms during neuronal differentiation. PCR products were analyzed in $6 \%$ polyacrylamide gel. The gels were stained with SYBR Green I and the images were analyzed in LAS 3000 (Fujifilm). The short isoforms ( $\mathrm{m} 2 \& \mathrm{~m} 3$ ) were highly expressed on Day 7 (neuronal cell stage), compared to the long isoform $(\mathrm{m} 1)$. 


\section{ACKNOWLEDGMENT}

Nor Hakimah Ab Hakim and Burhanuddin Yeop Majlis are supported in part by a Hi-COE Grant from the Higher Education Ministry of Malaysia. Hitoshi Suzuki and Toshifumi Tsukahara is supported in part by a Grant-in-aid for Scientific Research from the JSPS.

\section{REFERENCES}

[1] Sharma, S., Kohlstaedt, L., Damianov, A., Rio, D., and Black, D. L. Polypyrimidine tract binding protein controls the transition from exon definition to an intron defined spliceosome. Nature Structural and Molecular Biol. 15(2), 183-191 (2008). http://dx.doi.org/10.1038/nsmb.1375

[2] Li, Q., Lee, J. A. \& Black, D. L. Neuronal regulation of alternative pre-mRNA splicing. Nat. Rev. Neurosci. 8, 819 -831 (2007). http://dx.doi.org/10.1038/nrn2237

[3] Shin, C. \& Manley, J. L. Cell signaling and the control of pre-mRNA splicing. Nat. Rev. Mol. Cell Biol. 5, 727 -738 (2004). http://dx.doi.org/10.1038/nrm1467

[4] Smith, C. W. \& Valcarcel, J. Alternative pre-mRNA splicing: the logic of combinatorial control. Trends Biochem. Sci. 25, 381-388 (2000). http://dx.doi.org/10.1016/S0968-0004(00)01604-2

[5] Black, D. L. Protein diversity from alternative splicing: a challenge for bioinformatics and post - genome biology. Cell 103, 367-370 (2000). http://dx.doi.org/10.1016/S0092-8674(00)00128-8

[6] Graveley, B. R. Alternative splicing: increasing diversity in the proteomic world. Trends Genet. 17, 100-107 (2001). http://dx.doi.org/10.1016/S0168-9525(00)02176-4

[7] Johnson, J. M., Castle, J., Garrett-Engele, P., Kan, Z., Loerch, P. M., Armour, C. D., Santos, R., Schadt, E. E., Stoughton, R., and Shoemaker, D. D. Genome-wide survey of human alternative pre-mRNA splicing with exon junction microarrays. Science 302, 2141-2144 (2003). http://dx.doi.org/10.1126/science. 1090100

[8] Benjamin J. Blencowe. Alternative Splicing: New Insights from Global Analyses. Cell 126, 37-47 (2006). http://dx.doi.org/10.1016/j.cell.2006.06.023

[9] Matlin, A. J., Clark, F. and Smith, C. W. Understanding Alternative Splicing: Towards A Cellular Code. Nature Reviews Molecular Cell Biology 6, 386-398 (2005). http://dx.doi.org/10.1038/nrm1645

[10] Mc Burney

[11] Black, D. L. Mechanisms of alternative pre-messenger RNA splicing. Annu. Rev. Biochem. 72, 291-336 (2003). http://dx.doi.org/10.1146/annurev.biochem.72.121801.161720

[12] Wagner, E. J. and Garcia-Blanco, M.A. Polypyrimidine tract binding protein antagonizes exon definition. Mol. Cell. Biol. 21, 3281-3288 (2001). http://dx.doi.org/10.1128/MCB.21.10.3281-3288.2001

[13] Auweter, S., Fasan, R., Reymond, L., Underwood, J. et al. Molecular basis of RNA recognition by the human alternative splicing factor Fox -1 . The EMBO Journal 25, 163-173 (2006). http://dx.doi.org/10.1038/sj.emboj.7600918

[14] Hodgkin, J., Zellan, J., Albertson, D. Identification of a candidate primary sex determination locus, fox-1, on the $\mathrm{X}$-chromosome of Caenorhabditis elegans. Development 120, 3681-3689 (1994).

[15] Skipper, M., Milne, C. A., Hodgkin, J. Genetic and molecular analysis of fox-1, a numerator element involved in Caenorhabditis elegans primary sex determination. Genetics 151, 617-631 (1999).

[16] Fukumura, K., Kato, A., Jin, Y., Ideue, T. et al. Tissue-specific splicing regulator Fox -1 induces exon skipping by interfering E complex formation on the downstream intron of human F1 $\square$ gene. Nucleic Acid Research 1-9 (2007).

[17] Jin, Y., Suzuki, H., Maegawa, S., Endo, H., Sugano, S., Hashimoto, K., Yasuda, K. and Inoue, K. A vertebrate RNA - binding protein Fox-1 regulates tissue-specific splicing via pentanucleotide GCAUG. EMBO J. 22, 905-912 (2003).

http://dx.doi.org/10.1093/emboj/cdg089

[18] Kuroyanagi, H. Fox-1 family of R NA-binding proteins. Cell. Mol. Life Sci. 66, 3895-3907 (2009). http://dx.doi.org/10.1007/s00018-009-0120-5

[19] Komatsu, M., Kominami, E., Arahata, K., and Tsukahara, T. Cloning and characterization of two neural-salient serine/arginine-rich (NSSR) proteins involved in the regulation of alternative splicing in neurons. Genes to Cells 10, 593-606 (1999). http://dx.doi.org/10.1046/j.1365-2443.1999.00286.x

[20] Hakim, NHA, Kounishi, T., Alam, AHMK, Tsukahara, T., Suzuki, H. Alternative splicing of Mef2c promoted by Fox-1 during neuronal differentiation in P19 cells. Genes to Cell, 15, 255-267 (2010). http://dx.doi.org/10.1111/j.1365-2443.2009.01378.x

[21] Damianov, A. and Black, D. L. Autoregulation of Fox protein expression to produce dominant negative splicing factors. RNA 16, 405-416 (2010). http://dx.doi.org/10.1261/rna.1838210

[22] Yang, G. et.al. Regulated Fox-2 isoform expression mediates protein 4.1R splicing during erythroid differentiation. Blood 111, 392-401 (2008). http://dx.doi.org/10.1182/blood-2007-01-068940

[23] Ponthier, J.L., Schluepen, C., Chen, W., Lersch, R.A., Gee, S.L., Hou, V.C., Lo, A.J., Short, S.A., Chasis, J.A., Winkelmann, J.C., and Conboy, J.G. Fox-2 splicing factor binds to a conserved intron motif to promote inclusion of protein 4.1R alternative exon 16. J Biol Chem. 281, 12468-12474 (2006). http://dx.doi.org/10.1074/jbc.M511556200

[24] Suzuki, H., Osaki, K., Sano, K., Alam, AHMK, Nakamura, Y., Ishigaki, Y., Tsukahara, T. Comprehensive analysis of alternative splicing and functionality in neuronal differentiation of P19 cells. PLoS ONE, 6 (2), e16880 (2011) http://dx.doi.org/10.1371/journal.pone.0016880

[25] Newman, A. RNA enzymes for RNA Splicing. Nature 413, 695-696 (2001). http://dx.doi.org/10.1038/35099665

[26] Zhu, B., Ramachandran, B., and Gulick, T. Alternative pre-mRNA splicing governs expression of a conserved acidic transactivation domain in Myocyte Enhancer Factor 2 factors of striated muscle and brain. J. Bio.l Chem. 280, 28749-28760 (2005). http://dx.doi.org/10.1074/jbc.m502491200

[27] Suzuki, H., Jin, Y., Otani, H., Yasuda, K. and Inoue, K. Regulation of alternative splicing of alpha-actinin transcript by Bruno-like proteins. Genes Cells 7, 133-141 (2002).

http://dx.doi.org/10.1046/j.1356-9597.2001.00506.x 